\title{
Middle Miocene conoidean gastropods from western Ukraine (Paratethys): Integrative taxonomy, palaeoclimatogical and palaeobiogeographical implications
}

Daniele Scarponi, Giano Della Bella, Bruno Dell'Angelo, John Warren Huntley, and Maurizio Sosso Acta Palaeontologica Polonica 61 (2), 2016: 327-344 doi:http://dx.doi.org/10.4202/app.00158.2015

The late Badenian (early Serravallian) conoideans from the Pidhirtsi Beds of western Ukraine (central Paratethys) have been investigated by means of a comprehensive and easy-to-perform morphometric approach, allowing the characterisation of eleven species, of which seven are new to science: Mangelia angulicosta sp. nov., M. larga sp. nov., M. pseudorugulosa sp. nov., $M$. odovychenae sp. nov., Bela varovtsiana sp. nov., Bela? robusta sp. nov., Pyrgocythara turrispiralata sp. nov. Additionally we also identified Raphitoma cf. R. ringicula, Andonia sp. aff. A. transsylvanica , Teretia cf. T. turritelloides, and Haedropleura sp. aff. H. septangularis. The relative high number of new species documented, relative to the total previously known from this stratigraphic interval, is interpreted as resulting mainly from combined methodological (dearth of taxonomic studies on Ukrainian conoideans) and environmental (high degree of habitat fragmentation in reef setting) factors. The conoideans documented herein add important information regarding palaeoclimaticalogical and palaeobiogeographical interpretations of the Serravallian Paratethys. The conoideans display strong affinity at the species level and complete overlap at the genus level with Neogene Proto-Mediterranean-Atlantic conoideans, thereby challenging the interpretation of late Badenian Paratethyan macrofaunal assemblage endemism. The lack of typical warm-water indicators (e.g., Conidae, Clavatulidae, or Pseudomelatomidae) within the studied material supports the interpretation that the fauna thrived during the late phase and/or soon after the Middle Miocene Climatic Transition (14.2-13.8 Ma).

Key words: Conoidea, Middle Miocene Climatic Transition, Serravallian, Central Paratethys, Ukraine.

Daniele Scarponi [daniele.scarponi@unibo.it], Dipartimento di Scienze

Biologiche, Geologiche e Ambientali, Bologna University, Via Zamboni 67, 40126, Bologna, Italy. Giano Della Bella [enzo.dellabella@unibo.it], Museo Geologico Giovanni Capellini, Via Zamboni 63, 40126 Bologna, Italy. Bruno Dell'Angelo [bruno.dellangelo@ chitons.it], Museo di Zoologia, Via Selmi 3, 40126 Bologna, Italy. John Warren Huntley [huntleyj@missouri.edu], Department of Geological Sciences, University of Missouri, 101 Geology Building, Columbia, Missouri 65211, USA. Maurizio Sosso [sosmauri@gmail.com], Via Bengasi 4, 
16153 Genova, Italy.

This is an open-access article distributed under the terms of the Creative Commons Attribution License (for details please see creativecommons.org), which permits unrestricted use, distribution, and reproduction in any medium, provided the original author and source are credited.

\footnotetext{
FoF Full text $(1,456.9 \mathrm{kB})$

Far) Supplementary file $(804.0 \mathrm{kB})$
} 